\title{
Wakaf Saham Dalam Perspektif Hukum Islam*
}

\section{(ENDOWMENTS STOCK IN ISLAMIC LAW PERSPECTIVE)}

\author{
Siti Hanna \\ Fakultas Syariah dan Hukum UIN Jakarta \\ Jl. Ir. H. Juanda No. 95 CIputat Tangsel \\ Email: hannaghifar@yahoo.co.id
}

\begin{abstract}
Al-Quran and Sunnah did not explain the law of endowments clearly. Thus, it mostly decided through Ijtihad and based on the recent times. At the first, endowments is always static objects. However, it goes to many other objects today, such as endowments of profession, endowments of services, endowments of knowledge and the recent is endowments of stock. Those need intensive discussion to find the Islamic law perspektiv about it and the goal of the wakaf legitimation in Islam.
\end{abstract}

Keywords : Ijtihad, Endowments, Stock, Islamic Law, Schools

\begin{abstract}
Abstrak: Nash Alquran dan Sunnah tidak secara tegas membicarakan hukum wakaf, dan memang kebanyakan hukum wakaf dihasilkan lewat ijtihad dan ini membuat hukum wakaf berkembang sesuai dengan perkembangan zaman. Bila pada awalnya wakaf hanya berbentuk benda-benda yang tidak bergerak, namun seiring zaman, obyek wakaf mengalami perubahan, tidak hanya terbatas pada benda tidak bergerak, melainkan lebih luas merambah ranah yang lain. Muncul istilah wakaf profesi, wakaf jasa, wakaf ilmu dan yang terbaru wakaf saham. Semuanya ini memerlukan kajian khusus untuk mencari legitimasi syariah dan ketepatan tujuan pentasyrian wakaf dalam Islam.
\end{abstract}

Kata Kunci : Ijtihad, Wakaf, Saham, Hukum Islam, Madzhab

* Diterima tanggal naskah diterima: 13 Mei 2015, direvisi: 24 Mei 2015, disetujui untuk terbit: 22 Juni 2015. 


\section{Pendahuluan}

Pemberdayaan ekonomi umat Islam merupakan agenda penting yang kerap dibicarakan. Bentuk-bentuk transaksi muamalah dimaksimalkan dalam rangka peningkatan kesejahteraan umat Islam. Bahkan ibadah maliyah atau harta dioptimalkan sebagai sarana pemberdayaan ekonomi yang pada akhirnya akan mengangkat kesejahteraan umat Islam. Zakat, hibah, infak, sedekah dan wakaf merupakan bagian dari ibadah maliyah yang dapat dijadikan potensi peningkatan kesejahteraan.

Wakaf dalam bentuk konvensional hanya terbatas pada benda yang tidak bergerak, namun berdasarkan asas manfaat yang ingin disebarkan lewat wakaf ini, banyak obyek-obyek wakaf yang baru seperti halnya wakaf saham, dan ini tidak bertentangan dengan dasar-dasar hukum wakaf.

Spirit utama dalam wakaf adalah bagaimana memaksimalkan manfaat yang akan dirasakan oleh para penerimanya, sehingga tujuan wakaf untuk meningkatkan kesejahteraan umat Islam dapat terwujud.

\section{Pengertian Wakaf}

Wakaf secara bahasa berarti menahan dari kepindahan kepemilikan. Berasal dari kata waqafa - yaqifu - waqfan. Sinonim dengan at-tahbis dan attasbil. Sedangkan secara istilah syara' ada tiga definisi yang berlainan yang diungkapkan oleh beberapa madzhab (Wahbah az-Zuhaily : 1409 H / 1989M), yaitu :

1. Definisi waqaf menurut Abu Hanifah adalah menahan suatu benda yang menurut hukum tetap milik si pemberi wakaf, dalam rangka mempergunakan manfaatnya untuk kebajikan (Ibnu 'Abidin : 1415 H/1995 M). Berdasarkan definisi ini kepemilikan benda tidak hilang dengan adanya akad wakaf, akan tetapi tetap menjadi milik pemberi wakaf dan dia boleh menarik akad wakafnya itu, bahkan ia boleh menjualnya. Karena pendapat yang lebih kuat menurut Abu Hanifah adalah wakaf itu hukumnya boleh dan tidak mengikat seperti hukum pinjam memimjam, maka tidak berimplikasi mengikat kecuali dengan salahsatu sebab berikut:

Pertama, Keputusan mengikat datang dari hakim, misalnya wakif (pemberi wakaf) berselisih dengan nadzir (pengurus wakaf) karena wakif ingin menarik kembali wakafnya dengan alasan tidak ada hukum mengikat, lalu 


\section{Siti Hanna}

hakim memutuskan bahwa wakaf yang terjadi bersifat mengikat, maka hukum wakafnya menjadi mengikat, karena itu perkara yang diijtihadkan dan keputusan hakim dapat mengangkat perselisihan.

Kedua, Hakim menggantungkan keputusan mengikat sebuah wakaf dengan kematian pemberi wakaf, misalnya pemberi wakaf berkata : "Jika aku mati, maka aku wakafkan rumahku" misalnya, maka wakaf tersebut menjadi mengikat dengan adanya kematian seperti halnya wasiat dengan sepertiga peninggalan harta.

Ketiga, berwakaf untuk masjid, misalnya pemberi wakaf memisahkan sebagian dari tanah miliknya dan mengizinkan untuk dipakai shalat, maka jika seseorang shalat di tempat itu, hilanglah kepemilikan pemberi wakaf atas tempat itu menurut Abu Hanifah.

Abu Hanifah mendasarkan pendapatnya dengan dua dalil berikut :

Pertama, Hadis Rasulullah SAW. :

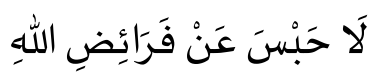

“Tidak ada penahanan dari ketentuan-ketentuan Allah".

Wajh ad-dalalah nya adalah bila wakaf bermakna mengeluarkan harta yang diwakafkan dari kepemilikan wakif, maka itu berarti menahan dari ketentuan Allah, karena telah menghalangi ahli waris dari bagian warisan yang ditentukan untuknya.

Wahbah mengomentari bahwa hadis ini tidak sejalan dengan maksud Imam Abu Hanifah, karena yang dimaksud adalah membatalkan kebiasaan jahiliyyah yang mengkhususkan warisan hanya untuk laki-laki, sementara wanita dan anak-anak tidak mendapat bagian (Wahbah az-Zuhaily : 1409 H / 1989M).

Kedua, Riwayat dari Qadhi Syuraih, ia berkata : Rasulullah SAW. telah menjual al-habs (barang-barang yang ditahan). Jika Rasulullah SAW telah melakukan itu, maka tidak boleh bagi kita membuat bentuk al-habs yang lain, karena wakaf bermakna tahbis al-al'ain, dan ini tidak disyariatkan.

Menurut Wahbah perkataan diatas tidak sejalan dengan maksud Imam Abu Hanifah, karena wakaf yang dilarang adalah wakaf benda sebagai persembahan kepada berhala. Rasulullah SAW telah menjual dan membatalkan penahanan ini sebagai bentuk penghapusan atas penyembahan 
berhala. Sementara wakaf bentuk yang murni islami (Wahbah az-Zuhaily : $1409 \mathrm{H} / 1989 \mathrm{M})$.

Definisi wakaf menurut Jumhur adalah menahan harta yang dapat dimanfaatkan tetapi bendanya tidak berkurang dengan mentransaksikan manfaat tersebut kepada bentuk transaksi yang dibolehkan atau kepada bentuk kebaikan dan derma demi mendekat kepada Allah Ta'ala. Dengan transaksi ini benda tresebut telah dikelurkan dari kepemilikan wakif dan menjadi benda wakaf yang dijadikan milik Allah Ta'ala. Wakif terlarang mentransaksikan benda yang diwakafkan dan harus mendermakannya.

Mereka berdalil dengan dalil berikut :

Pertama, Hadis Ibnu Umar : bahwa Umar mendapat bagian tanah di Khaibar, lalu ia bertanya : "Ya Rasulullah saya mendapat tanah di Khaibar, dan saya sama sekali belum pernah memiliki harta sebaik itu, maka apa yang engkau perintahkan untukku?", Rasulullah menjawab : "Jika engkau mau mau engkau tahan asalnya (bendanya) dan engkau sedekahkan manfaat darinya", maka Umar mensedekahkan manfaat tanah tersebut dengan tidak dijual, dihibahkan dan diwariskan. Manfaatnya diberikan kepada fuqara, kerabat, budak, tamu, dan ibnu sabil. Pengelola wakaf diperbolehkan makan bagian darinya dengan cara yang baik atau makan dengan tanpa bermaksud memperkaya diri". (Asy-Syaukani : t.t.)

Hadis ini menunjukkan larangan transaksi atas benda yang diwakafkan, karena al-habsu maknanya melarang, yakni melarang sebuah benda menjadi hak milik dan menjadi obyek transaksi kepemilikan. Akan tetapi dapat diperhatikan disini bahwa hadis ini tidak menunjukkan keluarnya harta yang diwakafkan dari kepemilikan wakif. (Wahbah azZuhaily : 1409 H / 1989M)

Kedua, Umat Islam sejak kedatangan Islam sampai sekarang selalu melakukan wakaf dengan tujuan kebaikan dan melarang wakif dan lainnya mentransaksikannnya.( Wahbah az-Zuhaily : 1409 H / 1989M)

Definisi madzhab Malikiyyah bahwa wakaf adalah perbuatan pemilik harta memberikan manfaat hartanya kepada pihak yang berhak menerima dengan sebuah shighat yang mengandung masa tertentu. (Ad-Dasuki : 1417 $\mathrm{H} / 1996 \mathrm{M})$ 


\section{Siti Hanna}

Pemilik benda menahan benda tersebut dari transaksi kepemilikan dan mendermakannya untuk kebaikan tetapi benda tersebut tetap menjadi milik wakif.

Wakaf menurut Malikiyyah tidak memutuskan hak kepemilikan atas benda yang diwakafkan, tetapi yang diputuskan adalah hak bertransaksi atasnya. Mereka berdalil dengan hadis Umar diatas, ketika Rasulullah SAW bersabda : "Jika kamu mau maka tahanlah pokok benda tersebut dan sedekahlah dengan manfaatnya". Hadis ini mengandung isyarat untuk bersedekah dengan manfaat sedangkan kepemilikan atas benda yang diwakafkan tetap dalam tanggungan wakif, dan melarang pihak lain melakukan transaksi kepemilikan atasnya, sebagaimana perkataan Umar : "Jangan dijual, dihibahkan dan diwariskan". (Wahbah az-Zuhaily : 1409 H / 1989M)

\section{Sejarah Perkembangan Wakaf}

Manusia telah mengenal berbagai macam wakaf sejak terbentuknya tatanan kehidupan bermasyarakat di muka bumi. Setiap masyarakat menyediakan pelayanan umum yang dibutuhkan oleh manusia secara keseluruhan atau kebanyakan anggota masyarakat. Tempat peribadatan adalah salahsatu contoh wakaf yang dikenal oleh manusia sejak dahulu kala. Demikian juga mata air, jalan-jalan, dan tempat-tempat yang sering digunakan masyarakat seperti tanah dan bangunan yang sering dipergunakan masyarakat, namum kepemilikannya bukan atas nama pribadi. Karena itu, tidak ada seorangpun yang mempunyai hak penuh untuk mengatur tempat itu, kecuali ia telah diberi mandat untuk pengelolaannya seperti para pemuka agama dan juru kunci. (Mundzir Qahaf : 2007)

Kebanyakan wakaf seperti yang telah disebutkan di atas dibangun oleh para raja dan orang-orang kaya pada zamannya, dengan memberikan hartanya untuk kepentingan seperti yang diinginkan wakif dan menunjuk orang-orang yang dipercayainya untuk mengelola dan mengawasinya. Wakaf tersebut biasanya berupa tanah, bangunan atau tempat yang sengaja disediakan untuk ibadah, praktik ritual keagamaan dan kegiatan agama lainnya yang bertujuan mendekatkan diri kepada Allah Ta'ala. (Mundzir Qahaf : 2007) 
Pengertian wakaf telah berkembang di kalangan sebagian masyarakat. Pada masa Fir'aun, masyarakat telah mengenal bentuk baru wakaf yang tidak ada sebelumnya. Bentuk wakaf ini berupa tanah pertanian yang diwakafkan oleh sebagian penguasa dan orang-orang kaya untuk tujuan bercocok tanam dan hasilnya diberikan kepada para tokoh spiritual yang pada saat itu dikenal sebagai dukun, baik dipergunakan untuk kepentingan pribadi mereka, mendanai tempat peribadatan yang berada di bawah pengawasannya atau diberikan kepada fakir miskin. Ini merupakan wakaf untuk kepentingan agama, karena penyalurannya dilakukan oleh para pemuka agama. (Mundzir Qahaf : 2007)

Ensiklopedia Grolyier internasional menyebutkan bahwa masyarakat Yunani telah mengenal bentuk wakaf seperti ini sebagaimana juga masyarakat Romawi. Demikian juga dinyatakan dalam Ensiklopedia Amerika, bahwa kebanyakan wakaf masyarakat Yunani dan Romawi adalah berupa perpustakaan umum, lembaga pendidikan dan tempat hiburan, disamping wakaf untuk kepentingan agama.

\section{Masa Islam}

Al-Quran menyebutkan bahwa ka'bah adalah tempat ibadah yang pertama bagi manusia, sebagaimana firman Allah Ta'ala :

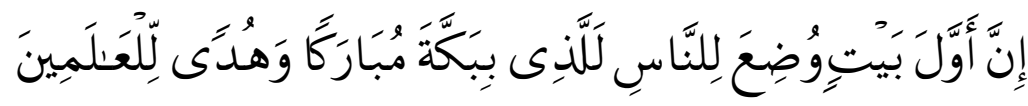

"Sesungguhnya rumah yang mula-mula dibangun untuk (tempat beribadat) manusia, ialah Baitullah yang di Bakkah (Mekah) yang diberkahi dan menjadi petunjuk bagi semua manusia". ( QS. Ali Imran : 96 )

Menurut pendapat yang mengatakan bahwa ka'bah dibangun oleh Nabi Adam alaihissalam, dan kaidah-kaidahnya ditetapkan oleh Nabi Ibrahim alaihissalam, serta dilestarikan oleh Nabi Muhammad SAW, maka dengan demikian ka'bah merupakan wakaf pertama yang dikenal oleh manusia dan dimanfaatkan untuk kepentingan agama. Sedangkan menurut pendapat yang mengatakan bahwa Nabi Ibrahim yang membangun ka'bah, maka ka'bah merupakan wakaf pertama kali dalam Islam, yaitu agama Nabi Ibrahim yang benar, atau wakaf pertama untuk kepentingan agama dan menegakkan tauhid. (Mundzir Qahaf : 2007)

Dalam sejarah Islam, wakaf dikenal sejak masa Rasulullah SAW karena wakaf disyariatkan setelah Nabi Muhammad SAW hijrah ke Madinah 


\section{Siti Hanna}

pada tahun kedua Hijriyah. Ada dua pendapat yang berkembang di kalangan fuqaha tentang siapa yang pertama kali melaksanakan syariat wakaf. Menurut pendapat sebagian ulama bahwa yang pertama kali melaksanakan wakaf adalah Rasulullah SAW, ketika ia mewakafkan tanahnya untuk dibangun masjid. Pendapat ini berdasarkan hadis yang diriwayatkan oleh Umar bin Syabah dari 'Amr bin Sa'ad bin Mu'ad, ia berkata :

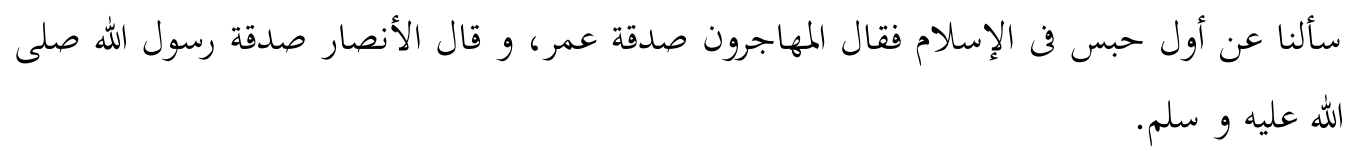

"Kami bertanya tentang awal mula wakaf dalam Islam, maka orang-orang muhajirin menjawab wakafnya Umar, sedangkan orang-orang anshor menjawab wakafnya Rasulullah SAW." (Asy-Syaukani : t.t.)

Wakaf sebagai sebuah hukum fikih memang disyariatkan pada tahun kedua Hijriyah, namun aplikasi wakaf sudah ada sejak awal hijrahnya Nabi Muhammad SAW ke Madinah yang ditandai dengan pembangunan Masjid Quba. Peristiwa ini terjadi setelah Nabi hijrah ke Madinah dan sebelum pindah ke rumah pamannya yang berasal dari Bani Najjar. Kemudian disusul dengan pembangunan masjid Nabawi yang dibangun di atas tanah anak yatim Bani Najjar setelah dibeli oleh Rasulullah SAW dengan harga delapan ratus dirham. Dengan demikian, Rasulullah SAW telah mewakafkan tanah untuk pembangunan masjid. Para sahabat juga telah membantu beliau dalam menyelesaikan pembangunan ini, termasuk pembuatan kamar-kamar bagi para istri beliau.

Rasulullah SAW pada tahun ketiga Hijriyah pernah mewakafkan tujuh kebun kurma di Madinah, diantaranya ialah kebun A'raf, Shafiyah, Dalal, Barqah dan kebun lainnya. (Direktorat Pemberdayaan Wakaf Depag RI : 2006) Perkebunan ini disebut tujuh perkebunan milik Mukhairik yang beragama Yahudi dan terbunuh dalam perang Uhud sebagai hasil perjanjian yang disepakati oleh umat Yahudi dan kaum muslimin untuk bersama-sama mempertahankan kota Madinah. Mukhairik menyuruh umat Yahudi untuk menepati janji, namun ternyata mereka mengingkarinya. Maka ia mengeluarkan ultimatum, bahwa jika dirinya terbunuh, perkebunannnya yang berjumlah tujuh menjadi milik Nabi Muhammad SAW dan dipergunakan sesuai kemaslahatannya. Nabi Muhammad SAW mengambil perkebunan itu setelah perang usai dan terbunuhnya Mukhairik. Beliau menyisihkan sebagian keuntungan dari perkebunan itu untuk memberi 
nafkah keluarganya selama satu tahun, sedangkan sisanya untuk membeli kuda perang, senjata dan untuk kepentingan kaum muslimin. (Mundzir Qahaf : 2007)

Menurut pendapat sebagian ulama mengatakan bahwa yang pertama kali melaksanakan syariat wakaf adalah Umar bin Khaththab, berdasarkan hadis yang diriwayatkan Ibnu Umar seperti tersebut sebelumnya. Kemudian syariat wakaf yang telah dilakukan Umar bin Khaththab disusul oleh Abu Thalhah yang mewakafkan kebun kesayangannya, kebun "Bairaha". Selanjutnya disusul oleh sahabat Nabi Muhammad SAW lainnya, seperti Abu Bakar yang mewakafkan sebidang tanahnya di Mekkah yang diperuntukkan kepada anak keturunannya yang datang ke Mekkah. Utsman menyedekahkan hartanya di Khaibar. Ali bin Abi Thalib mewakafkan tanahnya yang subur. Mu'adz bin Jabal mewakafkan rumahnya yang populer dengan sebutan Dar al-Anshar. Kemudian pelaksanaan wakaf disusul oleh Anas bin Malik, Abdullah bin Umar, Zubair bin Awwam dan Aisyah istri Rasulullah SAW. (Direktorat Pemberdayaan Wakaf : 2006)

Peristiwa sejarah yang sangat penting dan mungkin bisa dianggap sebagai peristiwa wakaf terbesar dalam sejarah manusia, baik dari sisi pelaksanaan maupun perluasan pemahaman tentang wakaf adalah wakaf tanah yang dibebaskan oleh Umar bin Khaththab ra. di beberapa negara, seperti Syam, Mesir dan Iraq. Hal ini dilakukan Umar setelah bermusyawarah dengan para sahabat, yang hasilnya adalah tidak boleh memberikan tanah pertanian kepada para tentara dan mujahid yang ikut dalam pembebasan tersebut. Sebab yang paling pertama berhak adalah umat Islam, sebagaimana dijelaskan dalam al-Quran, yang artinya :

"Apa saja harta rampasan (fai-i) yang diberikan Allah kepada RasulNya (dari harta benda) yang berasal dari penduduk kota-kota, maka adalah untuk Allah, untuk Rasul, kaum kerabat, anak-anak yatim, orang-orang miskin dan orang-orang yang dalam perjalanan, supaya harta itu jangan beredar di antara orang-orang kaya saja di antara kamu. Apa yang diberikan Rasul kepadamu, Maka terimalah, dan apa yang dilarangnya bagimu, maka tinggalkanlah. dan bertakwalah kepada Allah. Sesungguhnya Allah amat keras hukumannya. (Juga) bagi orang fakir yang berhijrah yang diusir dari kampung halaman dan dari harta benda mereka (karena) mencari karunia dari Allah dan keridhaanNya dan mereka menolong Allah dan RasulNya. mereka Itulah orang-orang yang benar. Dan orang-orang yang telah menempati kota Madinah dan telah beriman (Anshor) sebelum (kedatangan) mereka (Muhajirin), mereka (Anshor) mencintai orang yang berhijrah kepada mereka (Muhajirin), dan 


\section{Siti Hanna}

mereka (Anshor) tiada menaruh keinginan dalam hati mereka terhadap apaapa yang diberikan kepada mereka (Muhajirin) dan mereka mengutamakan (orang-orang muhajirin) atas diri mereka sendiri, sekalipun mereka dalam kesusahan Dan siapa yang dipelihara dari kekikiran dirinya, mereka itulah orang orang yang beruntung. Dan orang-orang yang datang sesudah mereka (Muhajirin dan Anshor), mereka berdoa: "Ya Rabb Kami, beri ampunlah Kami dan saudara-saudara Kami yang telah beriman lebih dulu dari Kami, dan janganlah Engkau membiarkan kedengkian dalam hati Kami terhadap orangorang yang beriman; Ya Rabb Kami, Sesungguhnya Engkau Maha Penyantun lagi Maha Penyayang." (QS. Al-Hasyr : 7-10)

Dengan mengambil dalil pada ayat ini, Umar memutuskan agar tanahtanah tersebut dijadikan wakaf bagi umat Islam dan generasi Islam yang akan datang. Bagi para petani pengguna tanah-tanah wakaf ini dikenakan pajak yang dalam istilah ekonomi Islam disebut pajak bumi. (Mundzir Qahaf : 2007)

\section{Masa Dinasti-dinasti Islam}

Praktek wakaf menjadi lebih luas pada masa dinasti Umayyah dan dinasti Abbasiyyah. Semua orang berduyun-duyun melaksanakan wakaf. Saat itu wakaf tidak hanya terbatas untuk orang fakir miskin saja, melainkan juga untuk mendanai lembaga pendidikan, membangun perpustakaan dan membayar gaji para stafnya, gaji para guru dan beasiswa untuk murid dan mahasiswa. Antusiasme masyarakat terhadap pelaksanaan wakaf telah menarik perhatian negara untuk mengatur pengelolaan wakaf sebagai sektor untuk membangun solidaritas sosial dan ekonomi masyarakat. (Direktorat Pemberdayaan Wakaf : 2006)

Pada masa dinasti Umayyah yang menjadi hakim Mesir adalah Taubah bin Ghar al-Hadhramiy pada masa khalifah Hisyam bin Abd al-Malik. Ia sangat perhatian dan tertarik dengan pengembangan wakaf sehingga terbentuk lembaga wakaf tersendiri sebagaimana lembaga lainnya di bawah pengawasan hakim. Lembaga wakaf inilah yang pertama kali dilakukan dalam administrasi wakaf di Mesir, bahkan diseluruh negara Islam. Pada saat itu juga Hakim Taubah mendirikan lembaga wakaf di Basrah. Sejak itulah pengelolaan lembaga wakaf di bawah Departemen Kehakiman yang dikelola dengan baik dan hasilnya disalurkan kepada yang berhak dan yang membutuhkan.

Pada masa dinasti Abbasiyyah terdapat lembaga wakaf yang disebut dengan "Shadr al-Wuquuf" yang mengurus administrasi dan memilih staf pengelola lembaga wakaf. Demikian perkembangan wakaf pada masa dinasti 
Umayyah dan Abbasiyyah yang manfaatnya dapat dirasakan oleh masyarakat, sehingga lembaga wakaf berkembang searah dengan pengaturan administrasinya.

Pada masa dinasti Ayyubiyyah di Mesir perkembangan wakaf cukup menggembirakan, dimana hampir semua tanah-tanah pertanian menjadi harta wakaf dan semuanya dikelola oleh negara dan menjadi milik negara (baitul mal). Ketika Shalahuddin al-Ayyuby memerintah Mesir, maka ia bermaksud mewakafkan tanah-tanah milik negara diserahkan kepada yayasan keagamaan dan yayasan sosial sebagaimana yang dilakukan oleh dinasti Fathimiyyah sebelumnya, meskipun secara fikih hukum mewakafkan tanah milik negara (baitul mal) kepada yayasan keagamaan dan sosial adalah Raja Nuruddin asy-Syahid dengan ketegasan fatwa yang dikeluarkan seorang ulama saat itu yaitu Ibnu 'Ishrun dan didukung oleh para ulama lainnya bahwa mewakafkan harta milik negara hukumnya boleh, dengan argumentasi memelihara dan menjaga kekayaan negara. Sebab harta yang menjadi milik negara pada dasarnya tidak boleh diwakafkan. (Direktorat Pemberdayaan Wakaf : 2006)

Shalahuddin al-Ayyuby banyak mewakafkan lahan milik negara untuk kegiatan pendidikan, seperti mewakafkan beberapa desa (qaryah) untuk pengembangan madrasah madzhab asy-Syafi'i, madrasah madzhab al-Maliki dan madrasah madzhab al-Hanafi dengan dana melalui model mewakafkan kebun dan lahan pertanian, seperti pembangunan madrasah madzhab asySyafi'i disamping kuburan Imam asy-Syafi'i dengan cara mewakafkan kebun pertanian dan pulau al-Fil. (Direktorat Pemberdayaan Wakaf : 2006)

Dalam rangka mensejahterakan ulama dan kepentingan misi madzhab sunni, Shalahuddin al-Ayyubi menetapkan kebijakan (572 H/1178 M) bahwa bagi orang Kristen yang datang dari Iskandaria untuk berdagang wajib membayar bea cukai. Hasilnya dikumpulkan dan diwakafkan kepada para fuqaha dan keturunannya. Wakaf telah menjadi sarana bagi dinasti alAyyubiyyah untuk kepentingan politiknya dan misi alirannya, madzhab sunni dan mempertahankan kekuasaannya. Harta milik negara menjadi modal untuk diwakafkan demi pengembangan madzhab sunni dan menggusur madzhab syi'ah yang dibawa oleh dinasti sebelumnya, yaitu dinasti Fathimiyyah. (Direktorat Pemberdayaan Wakaf : 2006 )

Perkembangan wakaf pada masa dinasti Mamluk sangat pesat dan beraneka ragam, sehingga apapun yang dapat diambil manfaatnya dapat 


\section{Siti Hanna}

diwakafkan. Akan tetapi yang paling banyak diwakafkan pada masa itu adalah tanah pertanian dan bangunan, seperti gedung perkantoran, penginapan dan tempat belajar. Pada masa Mamluk terdapat wakaf hamba sahaya yang diwakafkan untuk merawat lembaga-lembaga agama. Hal ini dilakukan pertama kali oleh penguasa dinasti Utsmani ketika menaklukkan Mesir, Sulaiman Basya yang mewakafkan budaknya untuk merawat masjid. Yang lebih membawa syiar Islam adalah wakaf untuk sarana di Haramain ; Mekkah dan Madinah, seperti kain penutup Ka'bah ( kiswah al-Ka'bah ). Sebagaimana yang dilakukan Raja Shaleh bin al-Nasir yang membeli desa Bisus lalu diwakafkan untuk membiayai kiswah ka'bah setiap tahunnya dan mengganti kain kuburan Nabi Muhammad SAW dan mimbarnya setiap lima tahun sekali. (Direktorat Pemberdayaan Wakaf : 2006 )

Perundang-undangan wakaf pada dinasti Mamluk dimulai sejak Raja al-Dhahir Bibers al-Bandaq, nama lengkapnya Beibers al-'Alai al-Bandaqdari as-Shalihi, lahir Qizaq tahun 625 H/1228 M, menjadi Raja di Mesir dan Syam pada tahun $658 \mathrm{H}$ dengan gelar Raja Dhahir. Wafat di Damaskus pada tahun 676 H/1277 M dan dimakamkan disana. ( Az-Zerekli : 1998 M). Dengan undang-undang tersebut beliau memilih hakim dari masing-masing empat madzhab Sunni. Pada masanya perwakafan dapat dibagi menjadi tiga katagori :

1. Pendapatan negara dari hasil wakaf yang diberikan oleh penguasa kepada orang-orang yang dianggap berjasa;

2. Wakaf untuk membantu Haramain (fasilitas Mekkah dan Madinah);

3. Wakaf untuk kepentingan umum. (Direktorat Pemberdayaan Wakaf : 2006)

Kerajaan Turki Utsmani juga mengeluarkan peraturan tentang perwakafan berupa undang-undang pada tanggal 19 Jumadil Akhir tahun 1280 Hijriyah. Undang-undang tersebut mengatur tentang pencatatan wakaf, sertifikasi wakaf, cara pengelolaan wakaf, upaya mencapai tujuan wakaf dan melembagakan wakaf. Pada tahun 1287 Hijriyah dikeluarkan undang-undang yang menjelaskan tentang kedudukan tanah-tanah kekuasaan Turki Utsmani dan tanah-tanah produktif yang berstatus wakaf. (Direktorat Pemberdayaan Wakaf : 2006) 


\section{Sejarah Perkembangan Wakaf di Indonesia}

Di Indonesia, wakaf telah dikenal dan dilaksanakan oleh umat Islam sejak agama Islam masuk di Indonesia. Pada tahun 1922 telah terdapat wakaf di seluruh Nusantara, mulai dari Aceh, Gayo, Tapanuli, Jambi, Palembang, Bengkulu, Minahasa, Gorontalo, Lombok, Jawa Timur, Jawa Tengah dan Jawa Barat. Nama dan benda yang diwakafkan berbeda-beda. Di Aceh disebut Wakeuh, di Gayo disebut Wokos, di Payakumbuh disebut Ibah. Benda yang diwakafkan ada yang berbentuk benda tidak bergerak seperti sawah, tanah kering, masjid, langgar, rumah, kebun karet, kebun kelapa dan benda bergerak seperti Al-Quran, sajadah dan batu bata. (Imam Suhadi : 2002)

Asset wakaf di Indonesia lebih banyak berbentuk tanah dan biasanya dipakai untuk kuburan, masjid dan madrasah, dan sedikit sekali yang didayagunakan secara produktif.

Pengelolaan wakaf di Indonesia mengalami masa yang cukup panjang. Terdapat tiga periode besar pengelolaan wakaf di Indonesia : (Direktorat Pemberdayaan Wakaf, Bunga Rampai Perwakafan, 2006)

Pertama, periode tradisional : wakaf masih ditempatkan sebagai ajaran murni yang dimasukkan dalam kategori ibadah mahdhah dimana hampir semua benda-benda wakaf diperuntukkan untuk kepentingan pembangunan fisik, seperti masjid, mushalla, pesantren, kuburan, yayasan dan sebagainya. Sehingga keberadaan wakaf pada periode ini belum memberikan kontribusi sosial yang lebih luas karena hanya untuk kepentingan yang bersifat konsumtif.

Kedua, periode semi profesional : pengelolaan wakaf yang kondisinya relatif sama dengan periode tradisional, namun pada masa ini sudah mulai dikembangkan pola pemberdayaan wakaf secara produktif meskipun belum maksimal. Sebagai contoh adalah pembangunan masjid-masjid yang letaknya strategis dengan menambah bangunan gedung untuk pertemuan, pernikahan dan acara lainnya seperti masjid Sunda Kelapa dan Pondok Indah di Jakarta.

Ketiga, Periode profesional : potensi wakaf sudah mulai dilirik untuk diberdayakan secara profesional-produktif. Profesionalisme yang dilakukan meliputi aspek manajemen, SDM kenazhiran, pola kemitraan usaha, bentuk benda wakaf bergerak seperti uang, saham dan surat berharga lainnya, dukungan political will pemerintah secara penuh, salahsatunya lahirnya UU 


\section{Siti Hanna}

Wakaf No. 41 Tahun 2004 tentang wakaf dan fatwa Majlis Ulama Indonesia tahun 2002 tentang legalitas kebolehan wakaf uang.

Bahkan, saat ini masyarakat miskin Indonesia telah merasakan manfaat wakaf dengan memanfaatkan layanan kesehatan cuma-cuma yang dibangun 2002 melalui dana wakaf yang dihimpun oleh lembaga tabung wakaf Indonesia. Wakaf tunai pun telah memberikan kesempatan bagi masyarakat miskin untuk belajar dan bekerja melalui investasi wakaf.

\section{Dasar Hukum Wakaf}

Wakaf menurut Jumhur Ulama kecuali Hanafiyah hukumnya adalah sunnah dan termasuk perbuatan derma yang dianjurkan. Sementara menurut Hanafiyah hukumnya adalah mubah berdasarkan dalil sahnya wakaf dari orang kafir. Akan tetapi bila seorang muslim bernadzar akan berwakaf maka hukumnya menjadi wajib. (Ibnu 'Abidin : t.t.)

Secara khusus tidak ditemukan nash al-Quran dan hadis yang secara tegas menyebutkan dasar hukum wakaf. Kebanyakan hukum wakaf memang dihasilkan lewat ijtihad. Tetapi secara umum banyak ditemukan ayat alQuran dan hadis yang menganjurkan agar orang yang beriman menyisihkan sebagian hartanya untuk didermakan di jalan kebaikan.

\section{Dasar Hukum dari Al-Quran}

Ayat-ayat al-Quran tidak secara eksplisit dan tegas menyebutkan perintah wakaf, tetapi perintah berwakaf tersebut tersirat lewat ayat-ayatnya yang memerintahkan kaum mukmin untuk berbuat baik dan ganjaran bagi orang yang menyisihkan sebagian hartanya di jalan Allah. Diantara ayat-ayat al-Quran yang dapat dijadikan sumber legitimasi wakaf adalah :

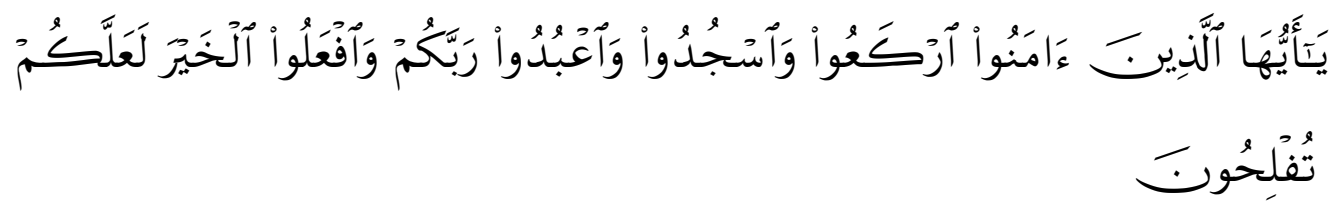

"Hai orang-orang yang beriman, ruku'lah kamu, sujudlah kamu, sembahlah Tuhanmu dan perbuatlah kebajikan, supaya kamu mendapat kemenangan." (QS. Al-Hajj : 77) 


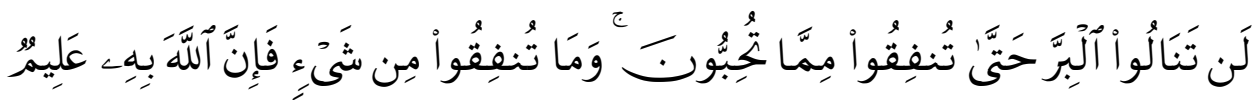

“Kamu sekali-kali tidak sampai kepada kebajikan (yang sempurna), sebelum kamu menafkahkan sehahagian harta yang kamu cintai. dan apa saja yang kamu nafkahkan Maka Sesungguhnya Allah mengetahuinya." (QS. Ali Imran : 92)

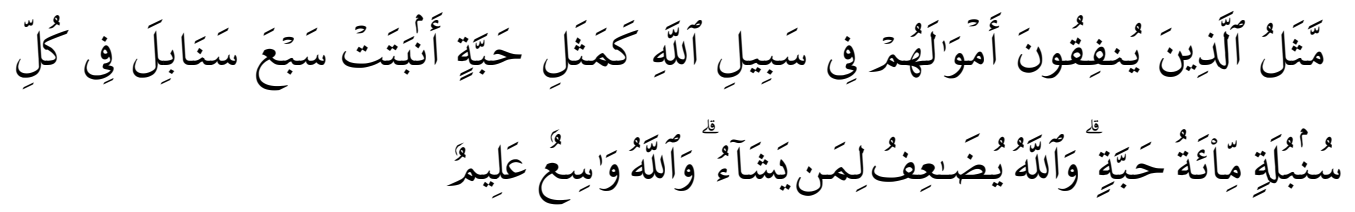

"Perumpamaan (nafkah yang dikeluarkan oleh) orang-orang yang menafkahkan hartanya di jalan Allah adalah serupa dengan sebutir benih yang menumbuhkan tujuh bulir, pada tiap-tiap bulir seratus biji. Allah melipat gandakan (ganjaran) bagi siapa yang Dia kehendaki, dan Allah Maha Luas (karunia-Nya) lagi Maha mengetahui." (QS. Al-Baqarah : 261)

Ayat-ayat diatas menganjurkan kepada orang mukmin untuk menyisihkan sebagian rezeki yang Allah berikan untuk diberikan kepada pihak-pihak yang berhak dan wakaf termasuk salahsatu cara menginfakkan harta di jalan Allah.

\section{Dasar Hukum dari Hadis}

$$
\begin{aligned}
& \text { عن أبي هريرة أن رسول الله صلى الله عليه و سلم قال : اذا مات ابن آدم انقطع عمله الا من ثلاث : } \\
& \text { صدقة جارية، أو علم ينتفع به، أو ولد صالح يدعو له. (رواه مسلم) }
\end{aligned}
$$

"Jika seorang manusia meninggal maka terputuslah segala amalnya kecuali tiga hal : shadaqah jariyah, ilmu yang bermanfaat, atau anak saleh yang mendoakannya". Ulama menafsirkan shadaqah jariyah dengan wakaf.

Ada hadis Nabi yang lebih tegas menganjurkan wakaf, yaitu perintah Nabi terhadap Umar bin Khattab untuk mewakafkan tanahnya yang ada di Khaibar :

$$
\begin{aligned}
& \text { عن ابن عمر رضي الله عنهما قال : أصاب عمر أرضا بخيبر فأتي النبي صلى الله عليه و سلم يستأمر } \\
& \text { فيها فقال : "يا رسول الله إني أصبت أرضا بخيبر لم أصب مالا قط هو أنفس عندي منه فما تأمربي } \\
& \text { به"، فقال له رسول الله صلى الله عليه و سلم : "إن شئت حبست أصلها و تصدقت بها"، فتصدق }
\end{aligned}
$$




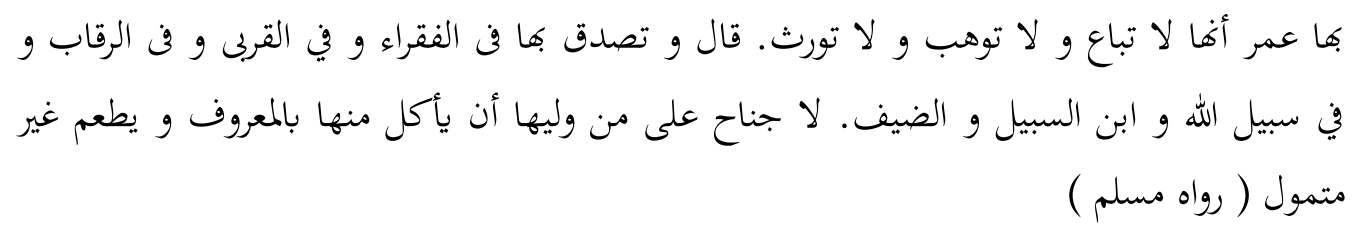

“Dari Ibnu Umar ra berkata, bahwa sahabat Umar ra memperoleh sebidang tanah di Khaibar, kemudian menghadap Rasulullah untuk memohon petunjuk. Umar berkata : "Ya Rasulullah, saya mendapatkan sebidang tanah di Khaibar, saya belum pernah mendapatkan harta sebaik itu, maka apakah yang engkau perintahkan kepadaku?", Rasulullah menjawab : "Bila kamu mau, kamu tahan (pokoknya) tanah itu, dan kamu sedekahkan (hasilnya)." Kemudian Umar mensedekahkannya : tidak dijual, tidak dihibahkan dan tidak diwariskan. Berkata Ibnu Umar : “Umar menyedekahkannya kepada orang-orang fakir, kaum kerabat, budak belian, sabilillah, ibnu sabil dan tamu. Dan tidak dilarang bagi yang mengurusnya untuk makan dari hasilnya dengan cara yang baik (sepantasnya) atau makan dengan tidak bermaksud menumpuk harta." (HR. Muslim)

Sedikit sekali memang ayat al-Quran dan as-Sunnah yang menyinggung wakaf. Karenanya sedikit sekali hukum-hukum yang terkait wakaf ditetapkan dengan dua sumber tersebut. Akan tetapi sumber hukum yang ada ini tetap menjadi pedoman para ulama ketika mengembangkan hukum wakaf dengan cara ijtihad. Kebanyakan hukum wakaf memang dihasilkan dengan cara ijtihad.

\section{Macam-macam Wakaf}

Wakaf terbagi menjadi beberapa macam berdasarkan tujuan, batasan waktunya dan penggunaan barangnya.

1. Macam-macam wakaf berdasarkan tujuannya ada tiga :

a. Wakaf sosial untuk kebaikan masyarakat (khairi ); yaitu apabila tujuan wakafnya untuk kepentingan umum;

b. Wakaf keluarga ( $d z u r r i$ ); yaitu apabila tujuan wakaf untuk memberi manfaat kepada wakif, keluarganya, keturunannya, dan orang-orang tertentu, tanpa melihat apakah kaya atau miskin, sakit atau sehat, dan tua atau muda.

c. Wakaf gabungan ( musytarak); yaitu apabila tujuan wakafnya untuk umum dan keluarga secara bersamaan. 
2. Sedangkan berdasarkan batasan waktunya, wakaf terbagi menjadi dua macam:

a. Wakaf abadi; yaitu apabila wakafnya berbentuk barang yang bersifat abadi, seperti tanah dan bangunan dengan tanahnya, atau barang bergerak yang ditentukan oleh wakif sebagai wakaf abadi dan produktif, dimana sebagian hasilnya untuk disalurkan sesuai tujuan wakaf, sedangkan sisanya untuk biaya perawatan wakaf dan mengganti kerusakannya.

b. Wakaf sementara; yaitu apabila barang yang diwakafkan berupa barang yang mudah rusak ketika dipergunakan tanpa memberi syarat untuk mengganti bagian yang rusak. Wakaf sementara juga bisa dikarenakan oleh keinginan wakif yang memberi batasan waktu ketika mewakafkan barangnya.

3. Berdasarkan penggunaannya, wakaf juga dibagi menjadi dua macam:

a. Wakaf langsung; yaitu wakaf yang pokok barangnya digunakan untuk mencapai tujuannya, seperti masjid untuk shalat, sekolah untuk kegiatan belajar mengajar, rumah sakit untuk mengobati orang sakit dan lain sebagainya.

b. Wakaf produktif; yaitu wakaf yang pokok barangnya digunakan untuk kegiatan produksi dan hasilnya diberikan sesuai dengan tujuan wakaf.

\section{Rukun dan Syarat Wakaf}

Dalam konsep fikih rukun adalah sesuatu yang menentukan kesahihan sebuah perbuatan. Sejauhmana rukun itu terpenuhi maka kesahihan perbuatan akan terwujud. Begitupun dalam perwakafan, ditentukan rukun-rukun yang menjadi pilar ibadah ini dan setiap rukun tersebut juga memiliki syarat-syarat tertentu. Adapun rukun-rukun wakaf adalah: (Asy-Syarbini : t.t.): 1). Wakif (orang yang mewakafkan); 2). Mauquf Bih (barang atau harta yang diwakafkan); 3). Mauquf 'Alaih (pihak yang diberi wakaf/peruntukan wakaf); 4). Shighat (pernyataan atau ikrar wakif sebagai suatu kehendak untuk mewakafkan sebagian harta bendanya) 


\section{Siti Hanna}

Setiap rukun diatas mempunyai syarat-syarat yang harus dipenuhi sehingga rukunnya dapat dianggap sempurna:

Pertama, Syarat-syarat wakif : (Wahbah az-Zuhaily : 1409 H / 1989 M): a). Seorang yang merdeka dan merupakan pemilik barang; b). Berakal; c). Baligh; d). Cerdas ; berarti memahami apa yang dilakukan, bukan orang yang berada dibawah pengampuan;

Kedua, Syarat-syarat Mauquf : (Wahbah az-Zuhaily : 1409 H / 1989 M): a). Benda yang diwakafkan adalah benda yang bernilai dan barang tidak bergerak; b). Benda yang diwakafkan diketahui kadar wakafnya, seperti ukuran luasnya tanah yang akan diwakafkan; c). Benda yang diwakafkan merupakan milik wakif dengan kepemilikan yang sempurna, maka tidak sah wakaf dengan barang yang masih dalam masa khiyar; d). Benda yang diwakafkan merupakan benda yang terpisah dari yang lain, tidak tercampur kepemilikannya dengan orang lain.

Ketiga, Syarat-syarat mauquf 'alaih: Mauquf 'Alaih ada dua macam : tertentu dan tidak tertentu. Yang dimaksud dengan tertentu adalah pihak yang menerima wakaf adalah orang-orang tertentu seperti satu orang, dua atau tiga yang sudah disebutkan secara definitif. Sedangkan yang tidak tertentu adalah pihak penerima bersifat umum tidak definitif menyebut satu orang, seperti kaum fakir, ulama, para qari, mujahidin, masjid-masjid, sekolah-sekolah dan lain-lain yang masih bersifat umum.

Ulama sepakat bagi penerima wakaf yang tertentu harus memiliki kelaikan untuk memiliki. Sedangkan syarat bagi penerima wakaf yang tidak tertentu adalah pihak umum yang menerima diketahui identitasnya dan merupakan tempat kebaikan. Wakaf kepadanya diniatkan untuk mendekatkan diri kepada Allah. Karenanya tidak boleh wakaf untuk tempattempat maksiat atau dipakai untuk kemaksiatan. (Wahbah az-Zuhaily : 1409 $\mathrm{H} / 1989 \mathrm{M}$ )

Keempat, Syarat-syarat yang harus ada dalam shighat/lafadz wakaf: (Wahbah az-Zuhaily : 1409 H / 1989 M):

1. Tidak sah wakaf dengan shighat yang menunjukkan pembatasan waktu, karena wakaf merupakan pengeluaran harta dengan tujuan mendekatkan diri kepada Allah, maka tidak terbatas dengan masa, bahkan harus mengandung makna kelanggengan; wakaf untuk selama-lamanya; 
2. Shighatnya mengandung makna tanjiz (langsung berlaku), wakafnya langsung terjadi saat pengucapan, tidak tergantung dengan syarat atau masa yang akan datang, karena wakaf merupakan akad yang berakibat pengalihan hak kepemilikan secara langsung, maka tidak boleh tergantung dengan syarat;

3. Mengandung makna ilzam (langsung berakibat hukum), tidak sah menggantungkan wakaf dengan khiyar;

4. Tidak bersambung dengan syarat yang batil;

5. Mengandung kejelasan kepada pihak mana wakaf akan diserahkan

\section{Wakaf Saham}

Berbicara tentang wakaf saham, penting untuk terlebih dahulu membicarakan jenis-jenis harta/benda yang dapat diwakafkan. Terjadi perubahan dan perkembangan hukum terhadap jenis harta wakaf. Bila fikih klasik kerap membicarakan wakaf dalam benda yang tidak bergerak, walaupun ada juga yang membicarakan wakaf manfaat-, maka perkembangan wakaf kontemporer tidak lagi membatasi hanya pada benda tidak bergerak, melainkan banyak bermunculan jenis harta yang dapat diwakafkan.

Berikut ini jenis harta wakaf yang disebutkan dalam undangundang di Indonesia. Jenis harta benda wakaf dalam Undang-undang Nomor 41 Tahun 2004 tentang wakaf terdiri dari : benda tidak bergerak dan benda bergerak. (UU No. 14/2004 tentang Wakaf, Pasal 16, ayat 1)

Benda tidak bergerak yang dimaksud dalam Undang-undang wakaf dapat dijabarkan sebagai berikut :

1. Hak atas tanah sesuai dengan ketentuan peraturan perundangundangan baik yang sudah maupun yang belum terdaftar;

2. Bangunan atau bagian bangunan yang berdiri di atas tanah sebagaimana dimaksud pada huruf a;

3. Tanaman dan benda lain yang berkaitan dengan tanah;

4. Hak milik atas satuan rumah susun sesuai dengan ketentuan peraturan perundang-undangan; dan 


\section{Siti Hanna}

5. Benda tidak bergerak lain sesuai dengan ketentuan prinsip syariah dan peraturan perundang-undangan. (UU No. 14/2004 tentang Wakaf, Pasal 16, ayat 2)

Sedangkan hak atas tanah yang dapat diwakafkan terdiri dari :

1. Hak milik atas tanah baik yang sudah atau belum terdaftar;

2. Hak atas tanah bersama dari satuan rumah susun sesuai dengan ketentuan peraturan perundang-undangan;

3. Hak guna bangunan, hak guna usaha atau hak pakai yang berada di atas tanah negara;

4. Hak guna bangunan atau hak pakai yang berada di atas tanah hak pengelolaan atau hak milik pribadi yang harus mendapat izin tertulis dari pemegang hak pengelolaan atau hak milik. (Direktorat Pemberdayaan Wakaf : 2006)

Benda bergerak sebagaimana dimaksud pada ayat (1) huruf $b$ adalah benda yang tidak bisa habis karena dikonsumsi, meliputi: Uang; Logam mulia; Surat berharga; Kendaraan; Hak atas kekayaan intelektual; Hak sewa; dan Benda bergerak lain sesuai dengan ketentuan syariah dan peraturan perundang-undangan yang berlaku. (UU No. 14/2004 tentang Wakaf, Pasal 16, ayat 3)

Benda bergerak selain uang dapat dijabarkan sebagai berikut :

1. Benda digolongkan sebagai benda bergerak karena sifatnya yang dapat berpindah atau dipindahkan atau karena ketetapan undangundang;

2. Benda bergerak terbagi dalam benda bergerak yang dapat dihabiskan dan yang tidak dapat dihabiskan karena pemakaian;

3. Benda bergerak yang dapat dihabiskan karena pemakaian tidak dapat diwakafkan, kecuali air dan bahan bakar minyak yang persediaannya berkelanjutan;

4. Benda bergerak yang tidak dapat dihabiskan karena pemakaian dapat diwakafkan dengan memperhatikan ketentuan prinsip syariah. (Direktorat Pemberdayaan Wakaf : 2006)

Ayat diatas dapat dijabarkan dalam berbagai klasifikasi benda bergerak; benda bergerak karena sifatnya, benda bergerak selain uang, benda 
bergerak berupa hak. Benda bergerak karena sifatnya yang dapat diwakafkan meliputi: Kapal; Pesawat terbang; Kendaraan bermotor; Mesin atau peralatan industri yang tidak tertancap pada bangunan; Logam dan batu mulia, dan/atau Benda lainnya yang tergolong sebagai benda bergerak karena sifatnya dan memiliki manfaat jangka panjang. (Direktorat Pemberdayaan Wakaf : 2006)

Benda bergerak selain uang karena peraturan perundang-undangan dapat diwakafkan sepanjang tidak bertentangan dengan prinsip syariah sebagai berikut: 1). Surat berharga yang berupa: Saham; Surat utang negara; Obligasi pada umumnya; dan/atau Surat berharga lainnya yang dapat dinilai dengan uang. 2). Hak atas kekayaan intelektual yang berupa: Hak cipta; Hak merk; Hak paten; Hak desain industri; Hak rahasia dagang; Hak sirkuit terpadu; Hak perlindungan varietas tanaman; dan/atau hak lainnya. (Direktorat Pemberdayaan Wakaf : 2006). 3). Hak atas benda bergerak lainnya yang berupa: Hak sewa, hak pakai dan hak pakai hasil atas benda bergerak; atau Perikatan, tuntutan atas jumlah uang yang dapat ditagih atas benda bergerak. (Direktorat Pemberdayaan Wakaf : 2006)

Melihat perundang-undangan diatas maka saham termasuk jenis harta yang diwakafkan, mengingat nilai dan manfaatnya yang tidak kecil.

\section{Pengertian dan Macam-macam Saham}

Saham adalah satuan nilai atau pembukuan dalam berbagai instrumen finansial yang mengacu pada bagian kepemilikan sebuah perusahaan. (Tjiptono Darmadji dan M. Fakhruddin Hendy : 2001).

Adapun macam-macam saham sebagai berikut : (Situs wikipedia.org : Saham, diakses pada tanggal 8 November 2011).

Pertama, Saham Biasa ( common stock), dengan karakteristik sebagai berikut : Hak suara pemegang saham, dapat memilih dewan komisaris; Hak didahulukan, bila organisasi penerbit menerbitkan saham baru; Tanggung jawab terbatas, pada jumlah yang diberikan saja.

Kedua, Saham Preferen ( preferred stock), dengan karakteristik sebagai berikut : Memiliki berbagai tingkat, dapat diterbitkan dengan karakteristik berbeda; Tagihan terhadap aktiva dan pendapatan, memiliki prioritas lebih tinggi dari saham biasa dalam hal pembagian dividen; Dividen kumulatif, bila 


\section{Siti Hanna}

belum dibayarkan dari periode sebelumnya maka dapat dibayarkan pada periode berjalan dan lebih dahulu dari saham biasa; Konvertibilitas, dapat ditukar menjadi saham biasa, bila kesepakatan antara pemegang saham dan organisasi penerbit terbentuk.

Bila ditinjau dari kinerja perdagangan, saham dapat dikelompokkan menjadi : 1). Blue chip stocks, saham biasa yang memiliki reputasi tinggi, sebagai pemimpin dalam industrinya, memiliki pendapatan yang stabil dan konsisten dalam membayar dividen; 2). Income stocks, saham suatu emiten dengan kemampuan membayarkan dividen lebih tinggi dari rata-rata dividen yang dibayarkan pada tahun sebelumnya; 3). Growth stocks, terdiri dari wellknown dan lesser-known; 4). Speculative stocks, saham secara konsisten memperoleh penghasilan dari tahun ke tahun, mempunyai kemungkinan penghasilan yang tinggi di masa mendatang, namun belum pasti; 5). Counter cyclical stocks, saham yang tidak terpengaruh oleh kondisi ekonomi makro maupun situasi bisnis secara umum.

Undang-undang nomor 40 tahun 2007 tentang Perseroan Terbatas, Pasal 53 ayat 3 dan 4 mengklasifikasikan saham sebagai berikut: 1). Saham biasa; diberikan kepada setiap orang yang memberikan pemasukan sejumlah uang kepada perseroan; 2). Saham dengan tanpa hak suara; pemilik saham ini tidak berhak mengikuti RUPS Perseroan, karena tidak mempunyai hak suara dalam pengambilan keputusan berkenaan dengan pengurusan Perseroan; 3). Saham dengan hak khusus untuk mencalonkan anggota direksi dan/atau anggota komisaris; 4). Saham yang dapat ditarik kembali; saham ini ditarik kembali atau ditukar dengan klasifikasi yang lain; 5). Saham yang memberikan hak dividen lebih dahulu; 6). Saham utama menerima lebih dahulu pembagian sisa kekayaan perseroan dalam likuidasi. (M. Yahya Harahap : 2009).

\section{Masyru'iyyah Wakaf Saham}

Wakaf saham termasuk wakaf produktif. Saham sebagai barang yang bergerak dipandang mampu menstimulus hasil-hasil yang dapat digunakan untuk kepentingan umat. Bahkan, dengan modal yang besar, saham mampu memberikan konstribusi yang cukup besar di banding jenis komoditas perdagangan yang lain. 
Dalam sebuah perusahaan, seorang pengusaha dapat mengkhususkan peruntukan sebagian sahamnya sebagai harta wakaf yang hasil/devidennya dialirkan untuk kemaslahatan umat. Wakaf saham boleh juga diambil dari keuntungan seluruh saham yang dimiliki sang pemilik. Semua tergantung pada keinginan dan kehendak sang pemilik saham. Sebab, yang penting bukanlah nominal besar-kecilnya hasil saham, melainkan lebih pada komitmen keberpihakan para wakif terhadap kesejahteraan umat Islam.

International Islamic Fiqh Academy dalam konferensi ke 19 yang bertempat di Uni Emirat pada tanggal 1-5 Jumadil Ula $1430 \mathrm{H} /$ bertepatan dengan 26-30 April 2009 M mengeluarkan keputusan tentang wakaf saham.

Konferensi ini mengeluarkan keputusan yang berisi kebolehan melakukan wakaf saham dengan pertimbangan bahwa wakaf merupakan salahsatu pembahasan fikih yang terbuka lebar menerima ijtihad. Ia termasuk ibadah yang dapat dinalar ( $m a^{\prime} q u l$ al-ma'na) yang terikat dengan tujuan syara', dengan tujuan mewujudkan kemaslahatan wakaf bagi wakif dan mauquf 'alaih. (Keputusan Ijtihad International Islamic Fiqh Academy No. 181 (7/19) tentang Wakaf Saham, Cek, Hak-hak Ma'nawi dan Manfa'at, Pasal 1 )

Nash-nash syara' yang terkait dengan wakaf berbentuk mutlak, masuk didalamnya wakaf yang bersifat abadi dan sementara, wakaf benda, manfaat dan uang, benda bergerak atau tidak bergerak, karena wakaf termasuk perbuatan derma, dan itu sangat luas dan dianjurkan. (Keputusan Ijtihad International Islamic Fiqh Academy No. 181 (7/19) tentang Wakaf Saham, Cek, Hak-hak Ma'nawi dan Manfa'at, Pasal 2 ayat 1)

Saham juga dapat diwakafkan dengan syarat saham tersebut mubah dimiliki secara syara', karena saham dianggap sebagai harta yang berharga secara syara'. Wakaf saham memiliki beberapa konsekwensi hukum, yaitu :

Pertama, Asal saham yang diwakafkan bersifat tetap, yang diwakafkan adalah keuntungan dari saham dan tidak diperjualbelikan di bursa efek, maka seorang nadzir tidak boleh mentransaksikannya kecuali untuk kemaslahatan atau sesuai dengan syarat yang diajukan wakif. Ia tunduk di bawah hukumhukum syara' yang dikenal dalam tatacara pergantian kepemilikan;

Kedua, Seandainya perusahaan melunasi atau membayar harga surat berharganya, maka boleh menggantinya dengan pokok wakaf yang lain seperti bangunan, saham dan surat berharga yang lain dengan syarat yang 


\section{Siti Hanna}

diberikan wakif atau berdasarkan kemaslahatan yang kembali kepada perwakafan;

Ketiga, Jika wakafnya bersifat temporer berdasarkan keinginan wakif maka ditunaikan sesuai syaratnya;

Keempat, Jika uang yang diwakafkan diinvestasikan untuk membeli saham atau surat berharga atau yang lainnya, maka saham dan surat berharga tersebut bukan menjadi harta wakaf menempati tempatnya uang selama wakif tidak mengatakan seperti itu, dan boleh dijual untuk investasi yang lebih banyak keuntungannya demi kemaslahatan wakaf, dan asal jumlah uang itulah yang menjadi harta wakaf yang ditahan. (Keputusan Ijtihad International Islamic Fiqh Academy No. 181 (7/19) tentang Wakaf Saham, Cek, Hak-hak Ma'nawi dan Manfa'at, Pasal 2 ayat 3, point 1-4)

Bila kita kembali pada pendapat ulama-ulama fikih terdahulu, pembahasan tentang wakaf saham ini dapat masuk ke dalam wakaf manfaat. Wakaf manfaat adalah apabila yang diwakafkan berupa manfaat yang dimiliki oleh selain pemilik barang, seperti dalam penyewaan. Ulama berbeda pendapat tentang wakaf manfaat ini.

Madzhab Hanafi dan Hambali berpendapat : seorang penyewa tidak dapat mewakafkan manfaat dari barang yang diwakafkan, karena mereka mensyaratkan keabadian kepemilikan dalam perwakafan, sedangkan penyewaan bersifat sementara dan tidak selamanya. (Al-Buhuti : t.t.)

Madzhab Syafi'i berpendapat : pemilik manfaat selain budak seperti orang yang menyewa dan orang yang diwasiatkan menerima manfaat tidak sah berwakaf dengan manfaat tersebut, akan tetapi kalau penyewa mewakafkan bangunan yang dibangun atau pohon yang ditanam di atas tanah yang disewa, maka sah wakafnya, dan terus berlangsung wakafnya sampai pemilik tanah merubuhkan bangunan atau mencabut pohon yang diwakafkan karena telah berakhir masa sewanya. (Ibnu 'Abidin : t.t.)

Madzhab Maliki berpendapat: penyewa boleh mewakafkan manfaat dari barang yang disewa selama masa persewaan yang disepakati, karena tidak disyaratkan kelanggengan atau keabadian perwakafan menurut mereka. Bahkan sah wakaf untuk kurun waktu tertentu. Tetapi yang menyewakan barang justru tidak boleh mewakafkan barang yang disewakan karena pada saat disewakan barang tersebut bukana menjadi miliknya. (AsySyarbini : t.t.) 
Akan tetapi menurut madzhab Hanafi dan Hambali pemilik barang yang disewakn boleh mewakafkan barang yang disewa, karena itu wakaf yang dimiliki, sedangkan penyewa cukup memanfaatkan manfaat barang yang disewa sampai habis masa persewaannya.

Kesimpulannya : menurut Jumhur sah wakafnya pemilik barang atas barang yang disewakan tetapi menurut madzhab Maliki tidak sah, sebaliknya menurut madzhab Maliki sah wakafnya penyewa barang atas manfaat barang yang disewa tetapi tidak sah menurut jumhur.

Menurut penulis, wakaf saham yang dinisbahkan ke dalam wakaf manfaat merupakan hal yang diperbolehkan, mengingat saham juga merupakan harta berharga dan manfaat yang diberikan dari wakaf saham sangat berarti bagi pemberdayaan umat. Apalagi mengingat tujuan wakaf adalah menyalurkan manfaat ke jalan kebaikan.

Wakaf manfaat yang dilakukan dalam batas waktu tertentu dari pemilik barang adalah menyerupai wakaf sementara bagi para ulama yang mengakui adanya wakaf sementara, sebagaimana yang mereka perdebatkan. Demikian juga manfaat barang tidak selamanya dimiliki oleh pemilik barang. Apabila seseorang memiliki manfaat suatu barang dalam jangka waktu tertentu, baik melalui sewa atau karena diberikan manfaatnya oleh pemilik barangnya, maka ia boleh mewakafkan manfaat barang tersebut selama masa untuk menggunakannya masih ada.

Contoh ini sama dengan orang yang menyewa bangunan selama 10 tahun, kemudian bangunan tersebut dijadikan masjid untuk shalat, atau memiliki manfaat atas binatang kemudian diwakafkan untuk angkutan jamaah haji, atau memiliki manfaat rumah selama setahun kemudian dijadikan untuk tempat penginapan orang yang sedang dalam perjalanan, dan lain sebagainya.

'Bahkan bila kembali kepada sejarah awal perwakafan, maka tindakan Umar bin Khaththab mewakafkan kebunnya di Khaibar dapat dikatakan sebagai bibit wakaf saham, karena kepemilikan kebun tetap ditangannya tetapi hasil kebun tersebut diwakafkan kepada orang-orang yang berhak menerimanya.

Hal lain yang harus diperhatikan dalam wakaf saham adalah bahwa saham yang diwakafkan haruslah saham untuk perusahaan yang bergerak pada bidang yang diperbolehkan agama. Perusahaannya tidak bergerak 


\section{Siti Hanna}

dalam hal-hal kemaksiatan. Maka tidak boleh berwakaf dengan saham perusahaan yang bergerak di bidang produksi minuman keras misalnya.

\section{Penutup}

Pertama, Nash al-Quran dan Sunnah tidak secara tegas membicarakan hukum wakaf, dan memang kebanyakan hukum wakaf dihasilkan lewat ijtihad dan ini membuat hukum wakaf berkembang sesuai dengan perkembangan zaman.

Kedua, Wakaf dalam bentuk konvensional hanya terbatas pada benda yang tidak bergerak, namun berdasarkan asas manfaat yang ingin disebarkan lewat wakaf ini, banyak obyek-obyek wakaf yang baru seperti halnya wakaf saham, wakaf jasa, wakaf ilmu dan ini tidak bertentangan dengan dasardasar hukum wakaf. Berkembangnya wakaf dapat dijadikan stimulus tumbuhkembangnya perekonomian kaum muslim.

Ketiga, Wakaf saham merupakan terobosan baru dalam perwakafan dan manfaat yang dihasilkan dari wakaf ini juga sangat besar. Karenanya wakaf dengan saham merupakan hal yang diperbolehkan.

\section{Pustaka Acuan}

Ad-Dasuki, Hasyiyah ad-Dasuki, Beirut : Dar al-Kutub al-'Ilmiyyah, 1417 $\mathrm{H} / 1996 \mathrm{M}$

Direktorat Pemberdayaan Wakaf, Bunga Rampai Perwakafan, Jakarta : Departemen Agama, 2006

Direktorat Pemberdayaan Wakaf, Fiqih Wakaf, Jakarta : Depag RI, 2006

Ibnu 'Abidin, Hasyiyah Radd al-Muhtar 'ala al-Durr al-Mukhtar, Beirut : Dar al-Fikr, 1415 H/1995 M

Imam Suhadi, Wakaf untuk Kesejahteraan Umat, Yogyakarta : PT. Dana Bhakti Prima Yasa, 2002

M. Yahya Harahap, Hukum Perseroan Terbatas, Jakarta : Sinar Grafika, 2009

Mundzir Qahaf, Manajemen Wakaf Produktif, penterjemah : H. Muhyiddin Mas Rida, Jakarta : Khalifa, 2007

Asy-Syarbini, Mughni al-Muhtaj, Kairo : Mushtafa Halabi, t.t. 
Asy-Syaukani, Nail al-Authar, Beirut : Dar al-Fikr, t.t.

Tjiptono Darmadji dan M. Fakhruddin Hendy, Pasar Modal di Indonesia, Jakarta : Salemba Empat, 2001

Az-Zerekli, al-A'lam, Beirut : Dar al-Ilmi lil Malayin, 1998 M

Wahbah az-Zuhaily, al-Fiqh al-Islamy wa Adillatuhu, Damaskus : Dar alFikr, 1409 H / 1989 M 